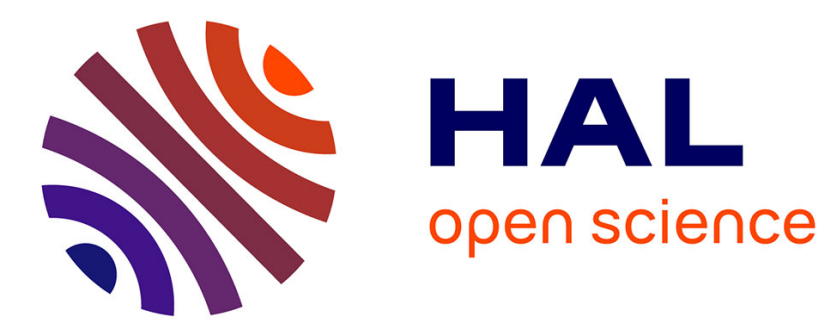

\title{
Should hyperthermic intraperitoneal chemotherapy be the new standard of care in ovarian cancer?
}

\author{
Vincent Lavoue, Cyrille Huchon, Emile Daraï
}

\section{To cite this version:}

Vincent Lavoue, Cyrille Huchon, Emile Daraï. Should hyperthermic intraperitoneal chemotherapy be the new standard of care in ovarian cancer?. Journal of Gynecology Obstetrics and Human Reproduction, 2018, 47 (10), pp.497. 10.1016/j.jogoh.2018.09.005 . hal-01940304

HAL Id: hal-01940304

\section{https://hal-univ-rennes1.archives-ouvertes.fr/hal-01940304}

Submitted on 14 Dec 2018

HAL is a multi-disciplinary open access archive for the deposit and dissemination of scientific research documents, whether they are published or not. The documents may come from teaching and research institutions in France or abroad, or from public or private research centers.
L'archive ouverte pluridisciplinaire HAL, est destinée au dépôt et à la diffusion de documents scientifiques de niveau recherche, publiés ou non, émanant des établissements d'enseignement et de recherche français ou étrangers, des laboratoires publics ou privés. 


\section{Should Hyperthermic Intraperitoneal Chemotherapy be the new standard of care in Ovarian Cancer?}

Vincent Lavoué ${ }^{1}, \mathrm{MD}, \mathrm{PhD}$, Cyrille Huchon ${ }^{2}, \mathrm{MD}, \mathrm{PhD}$, Emile Daraï ${ }^{3}, \mathrm{MD} \mathrm{PhD}$

1 Service de chirurgie gynécologique, CHU de Rennes, France. Unité INSERM 1242, Chemistry, Oncogenesis, Stress and Signaling, Centre Eugène Marquis, Rennes, France.

2 Service de gynécologie \& obstétrique, CHI Poissy-St-Germain, France. EA 7285 Risques cliniques et sécurité en santé des femmes, Université Versailles-Saint-Quentin en Yvelines, France.

3 Service de Gynécologie Obstétrique et Médecine de la Reproduction Humaine. Hôpital TENON, 75020, APHP, UPMC, Sorbonne Université PARIS, France

Corresponding Author: Pr Vincent Lavoué, vincent.lavoue@chu-rennes.fr. Service de gynécologie, CHU Hôpital Sud, 16 Bd de Bulgarie, 35000 RENNES, France. 
The article published in New England Journal of Medicine by van Driel et al. (Jan. 18 issue) ${ }^{1}$ shows that the addition of hyperthermic intraperitoneal chemotherapy (HIPEC) with cisplatin to cytoreductive surgery after neo-adjuvant chemotherapy resulted in better outcomes than surgery alone in patients with stage III epithelial ovarian cancer, with similar rates of side effects. Indeed, van Driel et al showed a significant overall survival median increase of 12 months with decrease of death rate of $37 \%$ at 5 years using HIPEC at interval cytoreductive surgery. These results were the best increase of overall survival in ovarian cancer since several decades.

This major trial could change ovarian cancer management in future. However, this new option in the management of advanced stages of ovarian cancer raises some concerns. First, it is crucial to emphasize on the establishment and application of criteria to define specialized centers to treat ovarian cancer. Furthermore, additional criteria will be required to define which specialized center could offer HIPEC in terms of medical team, case number by year, learning curve and intensive care unit availability. Third, national recommendations have to take into accounts these new evidences on HIPEC in interval surgery. Until today there is not enough centers in France that could perform HIPEC for around 2500 women per year diagnosed with ovarian carcinomatosis. This reinforces the need not only to define expert centers for HIPEC but also to allocate funding for this new but expensive strategy. Fourth, as discussed by Ceresoli et $\mathrm{al}^{2}$ about recurrence pattern following HIPEC, no data about site of recurrence was provided in van Driel et al trial. The peritoneal recurrence rate without systemic disease after cytoreductive surgery plus HIPEC was very low (14\% vs $43 \%$ without HIPEC) in Ceresoli study, suggesting peritoneal ovarian cancer disease is controlled, while systemic disease continues to evolve by itself, with $86 \%$ of systemic disease recurrence with HIPEC. Fifth, van Driel et al did not provide 
data about lymphadenectomy and lymph node involvement. These data are of particular interest because of they could modulate surgery duration and perioperative complication rate. In this new context of HIPEC, crucial questions with cytoreductive surgery plus HIPEC in ovarian cancer are the modulation of systemic recurrence rate and site of recurrence according lymph node status and according lymphadenectomy. Recent data from unpublished LION study showed that lymphadenectomy could be avoid in case of no visible lymph node involvement in ovarian carcinomatosis, with no modification of overall survival or disease free survival according lymphadenectomy randomization. Skipping lymphadenectomy could be adapted only to cytoreductive surgery without HIPEC where peritoneal recurrence appears as the main cause of death. It could be worth maintaining lymphadenectomy if systemic recurrence is confirmed as the main cause of death in cytoreductive surgery associated with HIPEC. Sixth, patients did not have bevacizumab in van Driel trial, which rise the tolerance of the bevacirumab use after HIPEC. Lastly, place of HIPEC in ovarian cancer management strategy has to be discussed in some particular cases such as patients with BRCA mutation, which could benefit from olaparib. Indeed, we don't know yet wether olaparib could overcome benefit of HIPEC or have an additive effect.

As postulated by Golfier et al in $2012^{3}$, but... "nul n'est prophète en son pays", HIPEC had to be judged based on evidence, now provided by van Driel trial. This major HIPEC trial is milestone in the ovarian cancer history and rises new issues in ovarian carcinomatosis treatment. A new era of treatment and research is now opened in ovarian cancer management.

\section{References:}

1. van Driel WJ, Koole SN, Sikorska K, et al. Hyperthermic intra- peritoneal chemotherapy in ovarian 
cancer. N Engl J Med 2018; 378:230-40.

2. Ceresoli M, Verrengia A, Montori G, et al. Effect of cytoreductive surgery and hyperthermic intraperitoneal chemotherapy on relapse pattern in primary epithelial ovarian cancer: a pro- pensity score based case-control study. J Gynecol Oncol 2018; 29:e53.

3. Bakrin N, Glehen O, Golfier F. HIPEC and ovarian carcinoma: base judgment on evidence. Gynecol Obstet Fertil 2012 Jan;40(1):1-3 